\title{
Accès aux centres neutroniques (ILL, LLB). Rédaction des demandes d'expériences
}

\author{
G. Cicognani
}

Institut Laue Langevin, SCO, 6 rue Jules Horowitz, 38042 Grenoble cedex 9, France

\section{Comment rédiger une demande d'expérience à l'ILL ou au LLB}

ANNEXE I

Comment obtenir du temps de faisceau à l'ILL

1. Submission of a proposal to the subcommittees

Application for beam-time via WEB

Section two, the scientific details for you proposal

Checklist

Mailing address

Deadlines of submission and schedule

Local contact

Review procedure for proposals

Experiment time schedules

Safety aspects

Payment of expenses by ILL

Publications

2. Submission of a proposal to the Fast Access Facility (FAST)

3. Submission of a proposal to the Director's Discretion Time (DDT)

4. Industrial applications

\section{ANNEXE II}

Comment obtenir du temps de faisceau au LLB

1. La soumission d'une expérience à un Comité de sélection (CS)

2. La soumission d'un projet expérimental pluriannuel. Tables Rondes

3. La soumission d'une proposition d'expérience à la. Direction du Laboratoire

4. La procédure d'accès 


\section{Comment rédiger une demande d’expérience à l'IL ou à LLB}

Ces notes ont pour but de vous guider dans la rédaction d'un demande d'expérience aupès de deux installations neutroniques situées en France, l'Institut Laue-Langevin (ILL, Grenoble) et le Laboratoire Léon Brillouin (LLB, Saclay). Des indications détaillées sur comment soumettre une proposition d'expérience à l'ILL ou au LLB sont données en annexe pour chaque laboratoire.

Les propositions doivent être soumises sous une forme standard et - pour l'ILL doivent être rédigées en anglais. Vous devez trouver un scientifique du laboratoire qui vous servira de 'local contact'. S'il s'agit de la poursuite d'une expérience, vous devez joindre le(s) rapport(s) des expériences précédentes.

Avant de commencer la rédaction de votre demande de faisceau, spécialement si c'est votre première, il est conseillé tout d'abord de discuter avec un scientifique du laboratoire concerné. Il peut vous aider à choisir l'instrument le plus adapté pour votre expérience et à calculer le temps de faisceau nécessaire.

Lors de la rédaction de votre texte, expliquez clairement les résultats que vous comptez obtenir de votre expérience et l'intérêt des neutrons par rapport à d'autres techniques (rayons $\mathrm{X}, \mathrm{NMR}$, etc. ).

Commencez votre demande de faisceau par un introduction expliquant les raisons pour lesquelles vous voulez faire cette expérience, pourquoi est-elle intéressante, quelle sera sa contribution à son domaine scientifique.

Expliquez ce que vous voulez faire, pourquoi vous avez choisi un instrument particulier et comment vous avez calculé le temps de mesure requis. Si des expériences d'essai ont été réalisées, indiquez les résultats. Les figures sont utiles à condition d'être bien expliquées et d'être suffisamment grandes. N'oubliez pas que les propositions sont généralement présentées dans un format réduit. Une proposition bien présentée et lisible a plus de chance d'être retenue ! 
Indiquez le nombre d'échantillons et donnez une estimation du temps de mesure pour chaque échantillon (vous devrez peut-être demander conseil à un membre du laboratoire des grands instruments concerné), cela vous permettra d'expliquer comment vous avez calculé le temps de faisceau nécessaire. Si vous avez les références de travaux déjà publiés se rapportant à votre expérience, indiquez les.

\section{Vade mecum pour la rédaction d' une proposition d'expérience :}

- donnez un bref aperçu sur l'importance générale de la recherche

- expliquez clairement les objectifs de l'expérience proposée avec une description détaillée; gardez à l'esprit que les membres des Comités d'évaluation ne sont pas tous des experts dans votre domaine spécifique

- reportez les résultats des éventuels travaux préliminaires que vous auriez effectués (NMR, rayons $X$, diffusion de la lumière, etc.) et détaillez leur rapport avec l'expérience proposée

- donnez le nombre d'échantillon à mesurer et estimez le temps de mesure pour chacun d'entre eux

- expliquez clairement pourquoi les neutrons sont nécessaires à votre expérience, et pourquoi l'utilisation d'un tel instrument et d'une telle installation (LLB ou ILL) est requise

- donnez une liste de références sur le sujet 


\section{ANNEXE 1 \\ Comment obtenir du temps de faisceau à I' III}

(guidelines from http://www.ill.fr)

There exist three different ways of submitting a proposal to the ILL

\section{Submission of a proposal to the Subcommittees}

You can submit your proposals only via the web. Detailed guidelines on our system for Electronical Proposal Submission (EPS) can be found on the ILL web.

\section{Application for beam-time vla weh}

The application for beam time on the internet consists of two sections.

The first section is a questionnaire, to be filled in on-line. It contains all the major information about the given proposal, such as the title, the name and address of the proposers, the sample description, the instrument and the beam-time required, the required resolution, energy and angular range, the

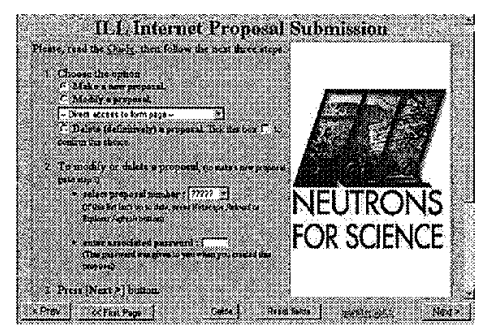
sample environment needed, the safety aspects and so on. You are also asked to provide an abstract of about 100 words.

The second part consists in your scientific text, which you have to write off line and upload as a postscript file.

\section{Section two, the scientific details for your proposal}

You will be asked at the end of the questionnaire to send your scientific text as a postscript file.

You are also given the possibility of submitting a technical form (see appropriate section).

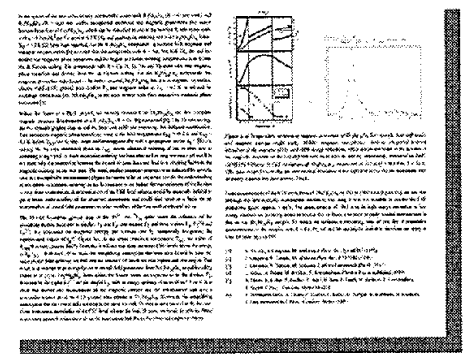




\section{Writing a proposal}

- give a brief statement of the background and the general importance of the research. - give a clear account of the aims of the proposed experiment and a detailed description of the experiment; keep in mind that not all of the subcommittee members are experts in the field.

- give results of preliminary work carried out, e.g. NMR, x-rays, light scattering, etc. and the relationship with your proposed experiment.

- give the number of samples and estimate the measuring time for each sample; show how you calculate the beam-time requirements.

- state why the ILL is necessary for your experiment, especially with regard to the need of neutrons in particular.

- include a list of relevant published literature.

- Please respect the maximum allowed space of two pages, additional sheets will not be forwarded to the Subcommittees members.

- For accepted proposals we will send an invitation with authorisation form to each participating laboratory. Please indicate one representative from each laboratory with complete address.

- For a continuation proposal you must attach the report from your previous experiment ( you can find detailed instructions on how to submit an experimental report via the web on http://www.ill.fr/index_sc.html ). Failure to do so may lead to rejection.

- For a "new" proposal it is recommended that in order to provide maximum information to the subcommittee you attach to your proposal copies of reports on your recent experiments on related topics.

- In all cases it is important to give references to your published work where this may help the subcommittee.

- You must have an ILL staff member as a local contact, who will assist in the measurement. Please verify with your local contact if the experimental conditions proposed are feasible. SCO will help you to find a local contact.

- Newcomers are recommended to establish contacts with experienced users. SCO will help you to find advice. 
- Proposers from non-member countries have to seek collaboration with scientists from member countries. Any beam time in collaboration with a non-member country will be counted entirely for the member country.

\section{Checklist}

\section{Have you:}

- filled in the sample description and safety aspect section?

- filled in the instrument and beam time requested?

- given the availabilty of sample and unacceptable dates?

-nominated a representative from each participating laboratory?

- included your experimental report for a continuation and (if appropriate) a "new" proposal?

- informed your local contact?

\section{Mailing address:}

\section{Institut Laue Langevin - SCO}

6, rue Jules Horowitz

\section{F-38 042 Grenoble Cedex 9, France}

tel: 04762070 82, fax: 0476483906

email: sco@ill.fr

\section{Deadlines of submission and schedule}

Deadlines for proposal submission are February 15 and August 31.

The web is open approximately $6-8$ weeks before.

\section{Local contact}

All external users carrying out an experiment at the ILL must have an institute staff member as a local contact, who will assist in the measurement. The local contact will also have had experience in running the instrument concerned thus ensuring efficient use of beam time.

In order to maintain close contact with the ILL, all external scientists submitting proposal should attempt to find an interested local contact themselves. In cases of difficulty, the appropriate college secretary may be able to suggest suitable ILL 
scientists, but it remains the responsibility of the proposer himself to establish links with individual ILL scientists. However, scientists or experimental groups wishing to use neutrons for the first time, will be given special consideration and are strongly advised to contact 'SCO' for further information.

\section{Review procedure for proposals}

All proposals requesting beam time which have been submitted to 'SCO' will be submitted to the subcommittees of the scientific council. The subcommittees whose members are specialists in relevant areas of this college evaluate the proposals; they are appointed by the ILL management. The subcommittees will assess the scientific merits, assigning priorities and beam time for accepted proposals. Before the meeting the subcommittee will receive a report on the technical feasibility of a proposed experiment by the appropriate college at the ILL.

The subcommittees and colleges are divided as follows:

- 3 nuclear and fundamental physics

- 4 structural and magnetic excitations

- 5A crystallographic structures

- $5 \mathrm{~B}$ magnetic structures

- 6 structure and dynamics of liquids and glasses

- 7 materials science, surfaces and spectroscopy

- 8 structure and dynamics of biological systems

- 9 structure and dynamics of soft-condensed matter

Immediately after each meeting of the subcommittees the proposer will be informed if his/her research proposal has been accepted. In the case of a rejection only brief general reasons are given as the ILL declines to enter into correspondence concerning decisions made by the scientific subcommittees.

\section{Experiment time schedules}

Accepted proposals submitted by February will receive beam time in the second half of the year and submitted by August in the first half of the next year.

Time schedules for a period of 6 months are normally compiled in the few weeks following the subcommittee meetings. This entails reserving the appropriate beam- 
time and issuing invitations for some 400 experiments. Clearly, proposers must make every effort to accept the dates suggested and any modifications or constraints must be communicated to 'SCO' as soon as possible after notification of the decision.

After receiving the invitation (the ILL sends one invitation per laboratory) please return the completed authorisation form to $\mathrm{SCO}$, so that you have no problems in entering the site, e.g. give the names of the actual people coming. Any substitution must be made known, not less than 24 hours before arrival. Visitors from non-EU countries should check visa requirements to enter France. Please bring your invitation form and some means of identification to enable entrance to the restricted ILL/ESRF site.

\section{Safety aspects}

Experimental conditions requiring special safety such as the use of radioactive isotopes or chemically or biologically hazardous materials or others should be clearly stated in the proposal. Any ancillary equipment supplied by the user must conform with the appropriate French regulations (if in doubt please contact the ILL safety engineer tel: 04762070 05, email : safety@ill.fr).

All users of the ILL facility must obey the local administrative and safety rules of the ILL. The sample-environment form attached to the invitation must be returned immediately to the ILL after completion (it has to be signed).

\section{Payment of expenses by the ILL}

Neutron beams and instrument facilities are free of charge for proposers of accepted experiments. Scientists affiliated with ILL member countries may be assisted with travel and daily subsistence for a limited period. Payment of these costs is limited to one scientists per experiment, or if scientists from different member-country establishments are included in the original proposal, this may be increased to a maximum of 2 visitors for each experiment.

Transport costs for major experimental equipment and subsistence allowances for data analysis carried out after the experiment cannot be paid by the ILL.

If you are in doubt about reimbursement please contact 'SCO' before your arrival at the ILL. 


\section{Publications}

Your results should be published giving proper credit to ILL staff members and proper mention of ILL facilities. ILL staff spend a considerable time building up the existing facilities which are put at disposal of users. The institute therefore considers it natural that ILL staff participating extensively in the performance of user experiments will have the right to be co-authored in publications.

For the acknowledgement of the ILL in scientific papers it is suggested that a footnote to the title of the paper be added on the first page, mentioning a temporary affiliation to the ILL for the duration of the work carried out.

\section{Submission of a proposal to the Fast Access Facility (FAST)}

In order to satisfy the demand to reduce long delays between proposal submission and beam time allocation, the ILL has introduced Faster Access Special beam Time (FAST) on specific instruments to cover scientific areas where fast response time is a crucial point. This option allows you to obtain quickly a limited number of days on a selected type of instruments. Fast Access is available twice a year, in June and December, in between the normal proposal submission dead-lines. Scheduling of the accepted proposals will be done within 6 weeks. FAST mode combines peer-review, confidentiality and short delay time. Research proposals can be submitted only through the web. The first appointment will take place in June 2001 and the 10 days available on each instruments are going to be scheduled from 9 to 19 August. Further information are available on the ILL web site (http://www.ill.fr/index_sc.html).

\section{Submission of a proposal to the Director's Discretion Time (DDT)}

This option allows you to obtain quickly beam-time, without going through the peerreview procedure. DDT is normally used for hot topics, new ideas, tests, new users.

\section{Industrial applications}

Proprietary industrial work is also possible at the ILL. Please contact the Industrial Liaison Responsible (Dr. Peter Lindner, lindner@ill.fr) for further details. 


\section{ANNEXE 2 \\ Comment obtenir du temps de faisceau à LBB}

( extrait du site http://www-llb.cea.fr/index_e.html)

L'accès aux neutrons est gratuit pour tout membre de la communauté scientifique française. Le LLB prend en charge les frais de mission de deux expérimentateurs pendant toute la durée de l'expérience (voyage et séjour).

Plusieurs voies sont possibles pour obtenir du temps de faisceau sur l'un des 25 spectromètres du LLB.

\section{La soumission d'une proposition d'expérience à un Comité de Sélection (CS)}

Cette procédure est ouverte à tout chercheur d'un laboratoire (public ou privé) qui souhaite, dans le cadre de sa thématique de recherche, exploiter les possibilités qu'offre la technique de diffusion des neutrons.

Les résultats obtenus doivent pouvoir être tout ou partie d'une publication dans un journal scientifique.

\section{Les Comités de Sélection du LLB se réunissent 2 fois par an.}

Les dates limites d'envoi des propositions sont le ler Avril et le ler Octobre de chaque année.

Vous trouverez sur le site web http://www-llb.cea.fr/proposals/index.html le document que vous devez remplir et nous renvoyer. Il vous demande :

des renseignements d'état civil et professionnels ;

un résumé de l'expérience envisagée remise dans sa problématique scientifique ;

diverses indications sur les conditions expérimentales souhaitées ;

les dangers potentiels que pourrait engendrer l'expérience projetée.

Ce document peut être rédigé en français ou en anglais. Il existe aussi sous forme "papier" que vous pouvez recevoir sur simple demande au Secrétariat Scientifique. 
Toutes ces propositions sont soumises à l'appréciation d'un Comité de Sélection par 1 ou 2 rapporteurs choisis en son sein.

\section{La soumission d'un projet expérimental pluriannuel - Tables Rondes}

Ouverte à tous, cette procédure offre la possibilité de proposer au Comité de Sélection l'ensemble d'un projet de recherche à réaliser par étapes et se poursuivant sur plusieurs années. Son acceptation implique, si le projet se déroule normalement, que le temps de faisceau demandé pour les années suivantes sera accordé.

Cette formule, ouverte à tous, permet aux Comités de Sélection d'apprécier l'ensemble d'un projet de recherche et assure aux proposants la continuité dans le temps de l'accès aux faisceaux de neutrons ainsi que, lorsque nécessaire, l'utilisation de plusieurs types de spectrométrie neutronique. Elle est, par exemple, tout-à-fait adaptée à un travail de thèse lorsque celui comporte une partie de mesures par diffusion neutronique.

Les projets pluriannuels peuvent être soumis 1 fois par an au Comité de Sélection qui suit nos Tables Rondes (présentation orale du projet à la Table Ronde).

La date limite d'envoi est le ler Octobre de chaque année.

Vous trouverez sur le site web de LLB: http:/www-llb.cea.fr/proposals/ plus de renseignements sur cette procédure ainsi que le document que vous devez remplir et renvoyer.

\section{La soumission d'une proposition d'expérience à la Direction du Laboratoire}

Cette procédure permet de raccourcir le délai entre la soumission et la réalisation de l'expérience. Non obligatoirement soumise à l'avis du Comité de Sélection, elle ne doit être utilisée qu'à titre exceptionnel : sujet chaud, anomalie dans le processus normal de sélection, ... confidentialité.

Ces propositions peuvent être examinées en continu, tout au long de l'année. 


\section{La procédure d'accès rapide}

Cette procéđure permet de réaliser, dans un délai de l'ordre de 1 à 2 mois, une expérience très courte ( 1 jour maximum) sur l'un de nos spectromètres. Test préliminaire, caractérisation, résultats complémentaires, .. peuvent être obtenus très rapidement.

L'expérience une fois réalisée, le proposant doit faire parvenir dans un délai de 6 mois au plus tard, son rapport d'expérience au Secrétariat Scientifique du LLB. 